To cite this article: Unegbu, V.E, Ezeudu, B., Babalola, Y.T.\& Madukoma, E. (2020) Imperatives of career development on librarians' commitment among university libraries in southern Nigeria. Information Impact: Journal of Information and Knowledge Management, 11:4, 107-116, DOI: https://dx.doi.org/10.4314/iijikm.v11i4.10

To link to this article: https://dx.doi.org/10.4314/iijikm.v11i4.10

\title{
Imperatives of Career Development on Librarians' Commitment among University Libraries in Southern Nigeria
}

\author{
${ }^{1}$ Unegbu, V. E \\ ${ }^{1}$ Ezeudu, B. \\ ${ }^{1}$ Babalola, Y.T \\ ${ }^{1}$ Madukoma, E. \\ ${ }^{1}$ Department of Information Resources Management, Babcock Universit, Ilishan-Remo, Ogun State, Nigeria
}

\begin{abstract}
This study examined the imperatives of career development on librarians commitment among university libraries in southern, Nigeria.The survey design was adopted for the study. A structured questionnaire was used to collect data from all the five hundred and fifty-six (556) professional librarians in thirty-nine public university in southern, Nigeria five hundred and twenty four (524) were completed and retrieved for data analysis. Total enumeration method was used to include all academic librarians in the universities in Southern Nigeria. Data was analyzed with descriptive statistics. The findings showed that the extent of career development was high and that out of the five construct, training contributed highest in librarian career development while counselingoffered the least contribution, although it was high.Affectiv commitment made the largest contribution while normative commitment offered the least contribution.Also, findings reviewed that career development significantly influenced librarians commitment at $<0.05$ significant level.The study recommends that the library managementcreates a friendly environment and organise regular staff trainingto boost librarians' commitment
\end{abstract}

Keywords Career development, Librarians commitment, Librarians, University libraries

CONTACT Unegbu V.E, Ezeudu B.,Babalola,Y.T and Madukoma E benebak@yahoo.comi Department of Information Resources Management Babcock University, Ilishan-Remo,Ogun State, Nigeria .

2020 The Authors Published with License by Information Impact

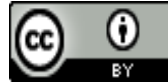




\section{Introduction}

Commitment is a state whereby employees show the highest level of dedication to support in the accomplishment of the organization's objectives (Owolabi, Ajiboye, Bakare, Bello, Omotoso, \&Adeleke, 2013). Commitment is a way to know how people respond emotionally and how it can be measured through the following attributes of attitude, beliefs, behaviour which can vary from low to high. Employee commitment refers to an employee's emotional attachment to, identification with, and involvement in an organisation.A committed librarian is indispensable to their institution because they take their work seriously and attract more users to the library. The commitment of librarian is very pertinent for delivering services in the area of user education, documentation, and reference services. The managements of libraries can increase the commitment of librarians by giving them recognition in foam of awards, sending them on training and conferences on the current trends of their professions. The focus of this current study is the employee commitment of librarians, knowing that the commitment of employee in an organization like library will help the library management to improve on absenteeism, low performance, and poor execution of excellent service to library users which are factors accountable for low commitment of librarians (Oyowvevotu 2018).

Commitment of librarians to their organisation could be centred on the three dimensions propanded by Meyer and Allen (1997), namely, affective, continuance and normative.These three dimensions of commitment explain the commitment of librarians. Hamidi, Mohammad -bakhsh, Soltanian and Behzadifar (2017) defined affective commitment as a situation where an individual fully accepts the rules guiding an organisation, and becomes personally and emotionally attached to that organisation's level of achievement. Continuance commitment occurs when an employee needs to stay in an organisation. Potential antecedents of continuance commitment include age, tenure and career satisfaction (Kim, Eisenberger, \& Baik, 2016). Normative commitment on the other hand is interpreted as the feeling that one ought to remain with the organization because of personal norms and values.For librarians to be well committed there is need for the development of their career,

Perrotta (2015) defined the concept of career development as the constant enhancement of knowledge and skills, comprising job mastery and professional development. She suggested that job mastery skills are those that are needed to perform one's job successfully. The benefit of career development is for both the employee and institution, and the employee development is for future position and this will lead to the assurance of the organization having an amount of competent, dedicated employee to substitute the higher-level employ. Additionally, career development trainings allow organizations to improve and place employees in locations attuned with their different career benefits, desires, and aims. This will go a long way stimulating the employee's fulfilment and ideal use of their skills. Career development involves the following components: career planning, coaching, counselling, mentoring, training and also the effective location of employees in positions that their needs and the needs of the organization will be met.

\section{Objectives of the study}

- ascertain the level of librarians commitment in university libraries in Southern Nigeria

- find out the extent of career development for librarians in university libraries in Southern Nigeria

\section{Research questions}

1 What is the level of librarians' commitment in university libraries in Southern, Nigeria?

2 What is the extent of career development of librarians in university libraries in Southern, Nigeria? 


\section{Research Hypotheses}

The following null hypothesis was tested at $0.05 \%$ level of significance for the study

Career development has no significant influence on librarians' commitment in university libraries in Southern Nigeria;

\section{Literature Review}

Committed employees perform better to the development of the organisation more than employees that are less commited. Zeena, et al (2018) defined commitment as away employees display a highest level of devotion to assist in the achievement of the organization's goals. Irefin, and Ali (2014) vied employee commitment as the highest level of dedication that a staff exhibits in an organization. Also in agreement, Mayowa-Adebara (2019)found that commitment is an emotional response that can be measured through people's behaviours, beliefs and attitudes. Similarly, Umar et al (2013) corroborated that, the employees of organizations whose work performance and productivity level of commitment is very high will perform better, while organizations whose employees have lower level of commitment will exhibit absence and unpunctuality. Organizational commitments consist of of three components which are affective, continuance and normative commitments. Affective commitment is a situation where an individual fully accepts the rules guiding an organisation, and becomes personally and emotionally attached to that organisations level of achievement.

Continuance commitment refers to awareness of the costs associated with leaving/quitting an organization. People with this type of commitment base their relationship with the organization on the remuneration they are getting from the organization and what they stand to lose if they leave the organization (Tutei, Koskei1, Geoffrey and Jared 2018).Continuance commitment occurs when an employee need to stay in an organisation. Potential antecedents of continuance commitment include age, tenure and career satisfaction (Kim, Eisenberger, \& Baik, 2016). Normative commitment means an obligation to uninterrupted employment which implies that somebody does not resign from an organization because of the pressures enforced by the statutes of the organization. Normative commitment is measured by the individual's feeling that they have to stay with the organization. Nitzche et al (2014) defined career development as a continuous process of work life, the author further stated that It helps people to recognise the gap that they lack in building up their skills and know how to develop it more in order to succeed through the time of change. Similarly, Anekwe, Ndubisi-okolo \& Nwannah, (2020) viewed career development. as a method of providing opportunities for employee's and organization to attain high and definite goals. Kemboi (2014) did a study on the perceived effect of career development practices on employee retention at the Kenya post office savings bank. During the study it was revealed that career development processes that are being practiced in Post Bank include the following, guidance and counselling, career planning, training coaching and mentoring. These are geared towards retaining of employees in the bank. The result shows that these processes of career development is used to support policymaking, providing direction to staff on career connected rights and responsibility, development of a healthy self-concept among individual employees and improve relationship and cooperation among staff at diverse levels. In a related empirical study, by Kelly (2012), on career development practices among commercial Banks in Kenya, result indicated that there are various career development practices that are obvious among commercial banks in Kenya which are- Treating career development as a core human resources function, existence of career growth information for employees, career counselling practice, integrating career growth into the appraisal process, The study made the following recommendation to employees to acquire higher education so as to upgrading skills, training program and undertaking of 
professional program. Foday (2014) did a similar study on perceived relationship between career development and employee retention at Deloitte Kenya. Descriptive, correlation and regression survey design was used for the study. The results shows that most of the respondents are satisfied with career planning as most of them display conformity to career planning best practices. Training and development, coaching and mentoring, career counselling services, succession planning and talent management were found to be suitable in the study area judging by most respondents. The result also suggests that employees are satisfied and propose to stay with the firm. In contrast to this background, inferential results added that among other factors, career planning, training and development, coaching and mentoring career counselling, succession planning and talent management are key influences of employee retention at Deloitte Kenya.

\section{Methodology}

The survey research design was employed for this study. The population of this study comprised 556 professional librarians from federal and state universities in South-East, South-West and South-South geo-political zones of Nigeria. Total enumeration technique was used to select the entire population. A structured questionnaire was used to collect data from the entire population of 556 professional librarians. Descriptive statistics such as frequency count, percentage distribution, mean and standard deviation were used to analyze data.The decision rule states that: 1.0-1.49 = Very low level of commitment; $1.50-2.49=$ Low level of commitment; 2.50-3.49 = High level of commitment; 3.50-4.0 = Very High level of commitment. Criteria mean of 2.5 is calculated as follows: $4+3+2+1=10 / 4=2.5$.

\section{Result}

Table 1: Level of librarians' commitment in university libraries in Southern, Nigeria

\begin{tabular}{|c|c|c|c|c|c|c|c|}
\hline Affective Commitment & $\begin{array}{l}\bar{\Phi} \\
\frac{\partial}{J} \\
\frac{1}{0} \\
\frac{0}{1} \\
\frac{\pi}{0}\end{array}$ & 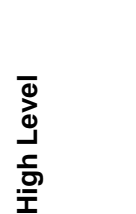 & 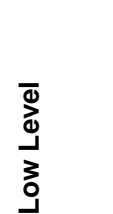 & 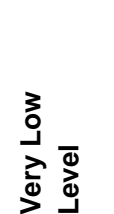 & Mean & SD & 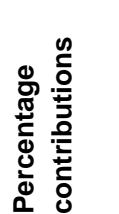 \\
\hline $\begin{array}{l}\text { My preference to work in this Institution over others at } \\
\text { the time I joined is }\end{array}$ & $\begin{array}{l}161(30 \\
.8)\end{array}$ & $333(63.8)$ & $10(1.9)$ & $18(3.5)$ & 3.22 & .65 & \multirow[t]{7}{*}{$35.8 \%$} \\
\hline $\begin{array}{l}\text { The willingness to put in more effort than expected in } \\
\text { this institution is }\end{array}$ & $\begin{array}{l}140 .(2 \\
6.8)\end{array}$ & $329(63.0)$ & $30(5.7)$ & $23(4.5)$ & 3.12 & .70 & \\
\hline My enthusiasm towards the institution is & $\begin{array}{l}115(22 \\
.0)\end{array}$ & $377(72.1)$ & $11(2.1)$ & $20(3.8)$ & 3.12 & .62 & \\
\hline My loyalty towards this institution is & $\begin{array}{l}125(23 \\
.9)\end{array}$ & $359(68.8)$ & $10(1.9)$ & $28(5.4)$ & 3.11 & .68 & \\
\hline My emotional attachment to this institution is & $\begin{array}{l}118(22 \\
.6)\end{array}$ & $353(67.4)$ & $27(5.2)$ & $25(4.8)$ & 3.08 & .68 & \\
\hline $\begin{array}{l}\text { The tendency for me to remain in this institution, even } \\
\text { to my disadvantage is. }\end{array}$ & $\begin{array}{l}83(15 . \\
9)\end{array}$ & $311(59.4)$ & $78(14.9$ & $51(9.8)$ & 2.81 & .82 & \\
\hline \multicolumn{7}{|l|}{ Group Mean = 3.08} & \\
\hline Continuance Commitment & & & & & & & \multirow[t]{4}{*}{$32.3 \%$} \\
\hline Happiness about choice of job is & $\begin{array}{l}74(14 . \\
3)\end{array}$ & $375(72.7)$ & $41(7.9)$ & $26(5.0)$ & 2.96 & .65 & \\
\hline Benefits from staying in this organization is & $\begin{array}{l}68(13 . \\
1)\end{array}$ & $337(65.1)$ & $84(16.2$ & $29(5.6)$ & 2.86 & .71 & \\
\hline $\begin{array}{l}\text { My tendency of accepting any type of job assignment } \\
\text { in order to keep working in this institution is }\end{array}$ & $\begin{array}{l}86(16 . \\
5)\end{array}$ & $308(59.1)$ & $87(16.7$ & $40(7.7)$ & 2.84 & .79 & \\
\hline
\end{tabular}




\begin{tabular}{|c|c|c|c|c|c|c|c|}
\hline $\begin{array}{l}\text { My aspiration to have lifetime employment if possible } \\
\text { with the organization is }\end{array}$ & $\begin{array}{l}57(10 . \\
9)\end{array}$ & $338(64.9)$ & 95(18.2 & $31(6.0)$ & 2.81 & .70 & \\
\hline $\begin{array}{l}\text { The possibility of leaving this institution even if I get a } \\
\text { better offer is }\end{array}$ & $\begin{array}{l}103(19 \\
.9)\end{array}$ & $201(38.8)$ & $189(36.5)$ & $25(4.8)$ & 2.74 & .83 & \\
\hline $\begin{array}{l}\text { The possibility of me spending the rest of my career in } \\
\text { this institution is }\end{array}$ & $\begin{array}{l}67(12 . \\
9)\end{array}$ & $287(55.2)$ & $127(24.4)$ & $39(7.5)$ & 2.73 & .78 & \\
\hline My thought of leaving this institution for another is & $\begin{array}{l}58(11 . \\
2)\end{array}$ & 172(33.1) & $256(49.2)$ & $34(6.5)$ & 2.49 & .78 & \\
\hline \multicolumn{8}{|l|}{ Group Mean = 2.78} \\
\hline Normative Commitment & & & & & & & \multirow[t]{8}{*}{$31.9 \%$} \\
\hline The obligation I have to work for the same institution & $\begin{array}{l}80(15 . \\
2)\end{array}$ & $381(73.2)$ & $28(5.4)$ & $32(6.2)$ & 2.98 & .67 & \\
\hline $\begin{array}{l}\text { The sense of loyalty which I feel this institution } \\
\text { deserves from me is }\end{array}$ & $\begin{array}{l}\text { 69(13. } \\
\text { 2) }\end{array}$ & $363(69.5)$ & $64(12.3)$ & $26(5.0)$ & 2.91 & .67 & \\
\hline The necessity for me staying in this organization is & $\begin{array}{l}58(11 . \\
1)\end{array}$ & $371(71.2)$ & $67(12.9)$ & $25(4.8)$ & 2.89 & .65 & \\
\hline $\begin{array}{l}\text { My obligation towards remaining with my current } \\
\text { employer is }\end{array}$ & $\begin{array}{l}61(11 . \\
7)\end{array}$ & $358(68.7)$ & $72(13.8)$ & $30(5.8)$ & 2.86 & .68 & \\
\hline $\begin{array}{l}\text { My desire to leave this institution because of the } \\
\text { strong sense of attachment to some people here is }\end{array}$ & $\begin{array}{l}54(10 . \\
3)\end{array}$ & $185(36.3)$ & $241(46.2)$ & $39(7.2)$ & 2.49 & .78 & \\
\hline Negative consequences of leaving the organization is & $48(9.2)$ & 163(31.4) & $251(48.4)$ & $57(11.0)$ & 2.39 & .80 & \\
\hline Group Mean = 2.75 & & & & & & & \\
\hline
\end{tabular}

\section{Source: Field work from the Researcher, 2020}

The result in Table 1 shows that the level of librarians' commitment in university libraries in Southern, Nigeria was high as indicated by the grand mean score of 2.87 on a four-point Likert type scale. The results reveal the percentage, mean, standard deviations, for each item on librarian commitment. The group mean and percentage contributions for each component and the grand mean for librarian commitment was calculated.

Table 2 Extent of career development of librarians in university libraries in southern, Nigeria.

\begin{tabular}{|c|c|c|c|c|c|c|c|}
\hline Training & 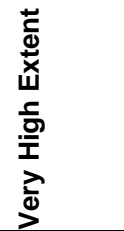 & 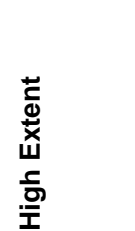 & 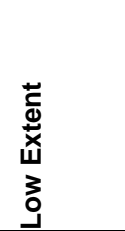 & $\frac{3}{0}+\frac{1}{0}$ & Mean & SD & 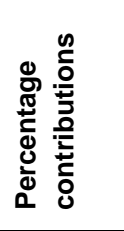 \\
\hline $\begin{array}{l}\text { The on-the-job training opportunity available for } \\
\text { employee }\end{array}$ & $79(13.7)$ & $358(68.8)$ & $54(10.4)$ & $37(7.1)$ & 2.89 & 0.72 & \multirow[t]{5}{*}{$20.2 \%$} \\
\hline $\begin{array}{l}\text { The rate at which the Institution allows employees } \\
\text { to have the time to learn new skills that prepares } \\
\text { them for future jobs. }\end{array}$ & $50(9.6)$ & $379(72.4)$ & $67(12.8)$ & $27(5.2)$ & 2.86 & 0.62 & \\
\hline $\begin{array}{l}\text { The opportunity for regular training on all cadres } \\
\text { of employee to enhance their engagement }\end{array}$ & $61(11.7)$ & $356(68.1)$ & $74(14.1)$ & $32(6.1)$ & 2.85 & 0.69 & \\
\hline $\begin{array}{l}\text { The adequate emphasis to develop managerial } \\
\text { capabilities through of-the-job training }\end{array}$ & $56(10.8)$ & $340(65.5)$ & $82(15.8)$ & $41(7.9)$ & 2.79 & 0.74 & \\
\hline \multicolumn{7}{|l|}{ Group Mean = 2.85} & \\
\hline Mentoring & & & & & & & \multirow[t]{4}{*}{$20.1 \%$} \\
\hline $\begin{array}{l}\text { Skilled professionals willingness to groom junior } \\
\text { professionals for higher positions. }\end{array}$ & $46(8.8)$ & $380(72.7)$ & $66(12.6)$ & $31(5.9)$ & 2.84 & 0.65 & \\
\hline The level of mentorship in your library. & $59(11.3)$ & $353(67.6)$ & $78(14.9)$ & $32(6.2)$ & 2.84 & 0.70 & \\
\hline $\begin{array}{l}\text { Junior employees' submission for grooming by } \\
\text { senior colleagues. }\end{array}$ & $54(10.4)$ & $355(68.0)$ & $83(15.9)$ & $30(5.7)$ & 2.83 & 0.68 & \\
\hline
\end{tabular}




\begin{tabular}{|c|c|c|c|c|c|c|c|}
\hline Group Mean = 2.84 & & & & & & & \\
\hline \multicolumn{7}{|l|}{ Career Planning } & \multirow[t]{4}{*}{$20.1 \%$} \\
\hline $\begin{array}{l}\text { The rate of career growth for staff in the } \\
\text { Organization }\end{array}$ & $45(8.6)$ & $376(72.0)$ & $78(14.9)$ & $23(4.4)$ & 2.85 & 0.62 & \\
\hline $\begin{array}{l}\text { The extent of career planning for staff of the } \\
\text { Organization. }\end{array}$ & $56(10.7)$ & $344(65.8)$ & $100(19.1)$ & $23(4.4)$ & 2.83 & 0.67 & \\
\hline $\begin{array}{l}\text { Discussion of career plan with staff before } \\
\text { decisions are taken on what is appropriate. }\end{array}$ & $74(14.2)$ & $316(60.8)$ & $93(17.9)$ & $37(7.1)$ & 2.82 & 0.76 & \\
\hline \multicolumn{8}{|l|}{ Group Mean = 2.83} \\
\hline Coaching & & & & & & & \multirow[t]{3}{*}{$20.1 \%$} \\
\hline $\begin{array}{l}\text { Developing staff for future positions in an } \\
\text { organization. }\end{array}$ & $57(10.9)$ & $373(71.5)$ & $70(13.4)$ & $22(4.2)$ & 2.89 & 0.63 & \\
\hline $\begin{array}{l}\text { The Organizational adaptation of formal } \\
\text { discussions about career development among its } \\
\text { employees }\end{array}$ & $36(6.9)$ & $377(72.5)$ & $84(16.2)$ & $23(4.4)$ & 2.82 & 0.61 & \\
\hline $\begin{array}{l}\text { Recognition of employees interests/goals by } \\
\text { Organizations }\end{array}$ & $48(9.2)$ & $344(65.9)$ & $98(18.8)$ & $32(6.1)$ & 2.78 & 0.69 & \\
\hline \multicolumn{8}{|l|}{ Group Mean = 2.83} \\
\hline Counseling & & & & & & & \multirow[t]{5}{*}{$19.5 \%$} \\
\hline $\begin{array}{l}\text { The extent of career the Organization prepares } \\
\text { forecast for each employee. }\end{array}$ & $53(10.1)$ & $335(64.1)$ & $107(20.5)$ & $28(5.3)$ & 2.79 & 0.69 & \\
\hline $\begin{array}{l}\text { The rate at which Organization provides guidance } \\
\text { to staff on career related rights and obligation in } \\
\text { the staff hand book. }\end{array}$ & $47(9.0)$ & $345(66.0)$ & $101(19.3)$ & $30(5.7)$ & 2.78 & 0.68 & \\
\hline $\begin{array}{l}\text { Provision of career counseling and } \\
\text { Planning assistance to employees by My } \\
\text { Institution. }\end{array}$ & $52(9.9)$ & $305(58.3)$ & $141(27.0)$ & $25(4.8)$ & 2.73 & 0.70 & \\
\hline $\begin{array}{l}\text { The procedure the Organization uses to dedicate } \\
\text { formal sessions for discussing career } \\
\text { Development of each staff. }\end{array}$ & $42(8.1)$ & $311(59.7)$ & $140(26.9)$ & $28(5.3)$ & 2.70 & 0.69 & \\
\hline \multicolumn{8}{|l|}{ Group Mean = 2.75} \\
\hline & Caree & ment & Mean $=$ & & & & \\
\hline
\end{tabular}

\section{Source: Field work from the Researcher, 2020}

According to the result of Table 2, the extent of librarians' career development in university libraries in Southern Nigeria, was high, based on the decision rule on the mean score of 2.95. The result signifies that librarians in university libraries of Southern, Nigeriahas a high career developmenton their job.

Research question: Career development has no significant influence on librarians' commitment in university libraries in Southern Nigeria;

Table 3: Multiple linear regression analysis of influence of career development (indicators) on librarians' commitment

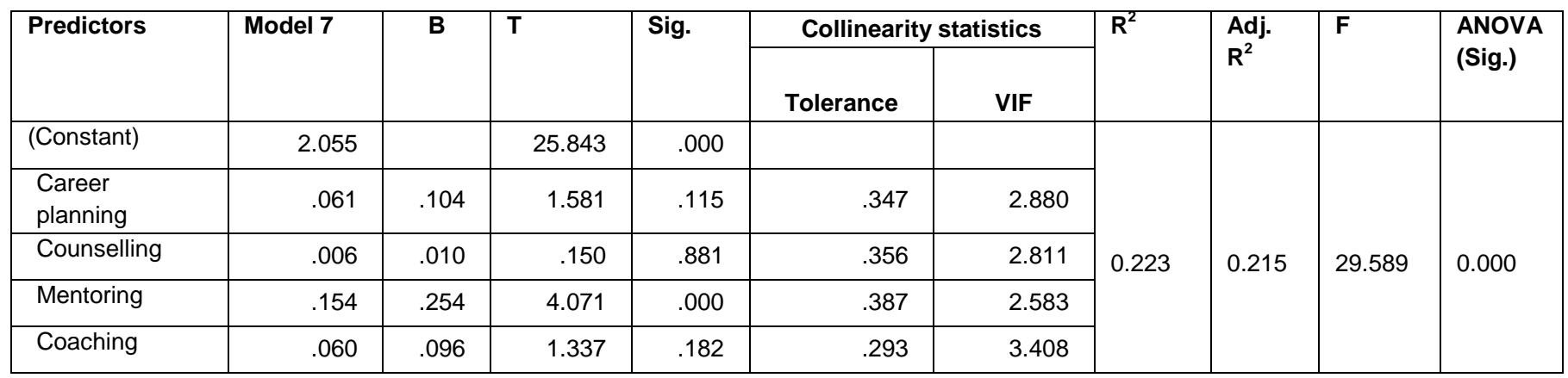




\begin{tabular}{|l|l|l|l|l|l|l|l|l|}
\hline Training & .046 & .071 & 1.179 & .239 & .412 & 2.426 & & \\
\hline Dependent Variable: Librarians' commitment \\
Predictors: (Constant), Career planning, Counselling, Mentoring, Coaching, Training \\
DF (F-Statistic) $=5,516$ \\
DF (T-Statistic) $=515$
\end{tabular}

\section{Source: Field Survey Results, 2019}

Table 3 presents the results of multiple linear regression analysis result for the influence of career development (indicators) on librarians' commitment in university libraries in Southern Nigeria. None of the career development (indicators) in the multiple linear regression indicate multicollinearity issues since their tolerance values were greater than 0.1 and VIF was less than 10 . Therefore, all the career development (indicators) were used in the multiple linear regression model. According to the result revealed in Table 4.7a, mentoring $(\beta=0.254, t(515)=4.071, p<0.05)$ has small, positive and significant influence onlibrarians' commitment in university libraries in Southern Nigeria. On the other hand, career planning $(\beta=0.104, t(515)=1.581, p>0.05)$, counselling $(\beta=0.010, t(515)=0.150, p>0.05)$, coaching $(\beta=0.096, t(515)=1.337, p>0.05)$, and training $(\beta=0.071, t(515)=1.179, p>0.05)$ had insignificant influences on librarians' commitment. The result shows that mentoring is the only contributor to librarians' commitment in university libraries in Southern Nigeria.

\section{Discussion}

Findings in Table1 reveal high level of job commitment in university libraries in Southern, Nigeria. Affective job commitment contributed the highest in job commitment while normative job commitment offered the least contribution. From this result, it implies that librarians are committed to their jobs. Therefore, library management should give credence to Librarians' job commitment dimensions captured in this study. Several empirical, conceptual and theoretical literature reviewed in the study corroborates this finding. For instance the finding is also consistent with that of Zeena, et al (2018) who defined commitment as away employees display a highest level of devotion to assist in the achievement of the organization's goals. The finding also corroborates Irefin, and Ali (2014) who found that the level of employee commitment of the staff of the company was very high. Also in agreement, Mayowa-Adebara (2019) found that commitment is an emotional response that can be measured through people's behaviours, beliefs and attitudes. Similarly, the finding of Umar et al (2013) corroborated that, the employees of organizations whose work performance and productivity level of commitment is very high will perform better, while organizations whose employees have lower level of commitment will exhibit absenteeism and lateness.

Research question two was formulated to probe into theextent of career development of librarians in university libraries in Southern, Nigeria..The question arose from the assumption that career development is needed to enhance job commitment of librarians in university libraries in Southern, Nigeria. Findings in Table 2 reveal high level of career development in university libraries in Southern, Nigeria. From the constructs measured, the table indicated that respondents rated on a high extent: training, mentoring, career planning, coaching and counseling. Training contributed highest to job commitment while counseling offered the least contribution to job commitment. This result provides insight into ways to facilitate better career development for librarians by paying attention to all the constructs captured in the study. Several empirical, conceptual and theoretical literature reviewed in the study corroborates this finding. This finding is also consistent with several other findings such as the work of Kemboi (2014) on the perceived effect of career development practices on employee retention 
revealed that career development processes that are being practiced in Post Bank include guidance and counselling, career planning, training, coaching and mentoring rated high level. The finding also agrees with the empirical review of Kelly (2012) who studied career development practices among commercial Banks and discovered that there are various career development practices that are obvious among commercial banks namely treating career development as a core human resources function, existence of career growth information for employees, career counselling practice and integrating career growth into the appraisal process. Likewise, Foday (2014) reported similar finding on perceived relationship between career development and employee retention. The result also suggests that employees are satisfied with career planning, training and development, coaching and mentoring career counselling, succession planning and talent management.

Hypothesis one which states that career development has no significant influence on librarians' commitment in university libraries in Southern Nigeria was formulated to ascertain the influence of career development on librarians' commitment. Findings revealed that career development has a significant influence on librarians' commitment in public universities in South-South, Nigeria. The null hypothesis was thus rejected. This result suggests that librarians who have been through career development on the job have strong tendencies to commit to their jobs. Several literature reviewed corroborates this finding. For instance, the empirical report of Muma, Iravo and Omondi (2014) on the effect of training needs assessment on employee commitment indicated that training had an influence on employee commitment. Likewise the finding supports that of Dome, Kemboi and KapkiaI (2017) who discovered that affective commitment positively influenced employee performance while training partially moderated the relationship between employee affective commitment and performance. The study was also consistent with Younis, Aame and Naseeb (2013) who investigated on career development and organizational commitment using four key parts of the human resource strategies namely planning, training and development, pay and reward and organizational commitment was what the researcher based the study. The result of the findings indicates that there is a significance influence of career development on organizational commitment. In the report of Ahmadi, et al (2018), librarians considered their career goals as important and valuable, successfully performed their assigned tasks, had a sense of belonging and commitment to organization, and enjoyed from their membership, a situation similar to this study. This situation was also evident in the empirical effort of Ekit (2012) who concludes that the bishop Stuart University use various motivational tools in appealing to its employees in order to maintain employees to employer's relationship, to help employees solve their problems and to encourage team work as well as improve on the employees confidence at their workplace to perform better for improved organizational employee performance. The finding is inconsistent with Ngetunyi (2013) who discovered that the main challenges faced by female employees in career development were education and training, lack of mentors, lack of access to informal networks and gender based discrimination

\section{Conclusion and Recommendation}

For an organisation to sustain his/her valuable employees, there is need for their career to be highly developed through training as one of the components of career development and as the construct that contributed more than others is highly needed to create commitment among librarians.Academic libraries be aware of the dynamic nature ofthe environment were they are situated which calls for them to be preemptive, advanced and receptive. Consequently, this study recommends that the management of academic libraries in southern, Nigeria should creates a friendly environment to boost librarians' commitment and also organise regular staff training to enhance librarian's commitment. 


\section{References}

Ahmadi, M., Yousefianzadeh, O., Taheri, A., Abdollahi, S. Z. \& Majid, H. (2018). The relationship between psychological empowerment and job satisfaction and organizational commitment of librarians in libraries affiliated to Iran University of Medical Sciences. Revista Publicando, 14 (3): $615-625$.

Anekwe, R. A., Ndubisi-okolo, P \& Nwannah, C. P (2020) Career development and Employee performance of banks in Anambra state, Nigeria. International Journal of accounting, finance and management research, 4(3) 1-9

Eisenberger, B.O\& Baik,(2016) Perceived organizational support and affective organizational Commitment: Moderating influence of perceived organizational competence. Journal of Organizational behavior,37(4),494

Ekit, F (2012) Motivation and employee performance in organization: A case study of Bishop Stuart University, a research report submitted to the faculty of business and developmental studies in partial fulfillment of the requirement for the award of a degree in business administration of Bishop satuart University.

Foday, A. (2014). Perceived relationship between career development and employee retention At Deloitte Kenya. A Research Project Submitted In Partial Fulfilment Of The Requirements for the Award of the Degree of Master of Business Administration, School Of Business, and University Of Nairobi.

Hamidi1, Y., Mohammad B. R., Soltanian, A. \& Behzadifar, M. (2017). Relationship between organizational culture and commitment of employees in health care centers in west of Iran. Electronic Physician, 9(1), 3646-3652

Irefin, P \& Ali M (2014). Effect of Employee Commitment on Organizational Performance in Coca Cola Nigeria Limited Maiduguri, Borno State. Journal Of Humanities And Social Science,3 (19), 3341

Kelly, U. (2012). Career Development Practices among CommercialCounty sin Kenya.

Kemboi, U. \& Kapkia, O (2017). Effect Talent Management Strategies on employee Retention Among private firms in Kenya: A case of Data centre Ltd. International Academic Journal of Human Resources and Business administration,5(2), 145-157.

Mayowa-Adebara, O. (2018). The influence of leadership style, organizational justice and human capital development on employee commitment in university libraries in South-West, Nigeria. Library Philosophy 
Meyer, J. P. \& Allen, N. J. (1997). Commitment in the workplace: Theory, research and application. Thousand Oaks: Sage.

Muma, M., Iravo.,A,\& Omondi, M (2014) Effect of Training Needs Assessment on Employee Commitment in Public Universities: A Case Study of Jomo Kenyatta University of Agriculture and Technology. International Journal of Academic Research in Business and Social Sciences, 4( 9),233-250

Ngetuny,, E. J.(2013).Challenges Faced By Female Employees In Career Development At Chemelil Sugar Company Kenya.. Thesis submitted to University of Nairobi, Kenya.

Nitzsche, A., Jung, J., Kowalski, C., \& Pfaff, H. (2014). Validation of the WLB Culture Scale (WLBCS). Work, 49(1), 133-142. doi:10.3233/WOR-131643

Okoye, J. C. (2008). Current Developments in Academic Libraries in Developing Countries. Enugu: Trans boarder Book.

Oyovwevotu, L. (2018). Institution support, job satisfaction and employees' commitment in public u niversity libraries in South-East geo-political zone, Nigeria (Unpublished Doctoral dissertation). Babcock University, Ilisan-Remo, Nigeria.

Owolabi, K. A., Ajiboye, B. A., Bakare, O.D., Bello, T.O., Omotoso, A.O \& Adeleke, O. (2013). Librarians attitude toward monetary and non-monetary incentives in university libraries: A case study of selected university libraries in Nigeria. Annals of Library and Information Studies, 60 (30), $22-26$.

Perrotta, V. (2015). Career advice: Meet career international. Journal of Indian psychology, 4(2), 22-26

Tutei, A., Geoffrey, K \& Jared B. (2018). Continuance commitment and employee performance at university of Eastern Africa, Baraton Kenya.Journal of Business and Management (), 20(2), 5868.

Umar, A., Sale, Y \& Yahaya, Y. (2013). Assessing the relationship between organizational Commitments: Stresses and technological stress in Organization. Journal of Humanities and social sciences, 17(4), 68-74.

Younis, N., Aame, A. \& Naseeb, A. (2013). Career development and organizational commitment: Case study of a pharmaceutical organization in United Kingdom. International Journal of Scientific and Research Publications, 3(12), 1-4.

Zeena, F. \& Souza D. ( 2018) Employee Attitude towardsOrganizational Commitment: A Literature Survey. IOSR Journal of Business and Management ,20. (1), 21-27. 